\title{
The Development of Science Learning Material with Local Wisdom Content to Train Students' Critical Thinking
}

\author{
Sundari $^{1}$, Ani Rusilowati ${ }^{2}$, Putut Marwoto ${ }^{3}$ \\ \{sundari.wsb@gmail.com ${ }^{1}$, rusilowati@yahoo.com ${ }^{2}$, pmarwoto@yahoo.com $^{3}$ \} \\ Graduate School, Universitas Negeri Semarang, Indonesia ${ }^{1,2,3}$
}

\begin{abstract}
Critical thinking of Indonesian students showed low categories. Critical thinking can be train, one of them, by developing learning material. This research tested validity and effectiveness of science learning material under material, such as vibration, signal and sound with local wisdom content to train students' critical thinking. This $4-D$ model (Define, Design, Develop, and Disseminate) showed: (1) the developed learning material averagely scores 80.94 and 92.68 (valid and extremely valid) by expert validators and practitioner; (2) the effectiveness of learning material in training critical thinking average scores was 0.73 through $N$-gain test and hypothesis test by using paired sample t-test with sig score $0.000<\alpha=0.05$. Therefore, there was difference of the students' critical thinking before and after the intervention. It is concluded that the learning material met the requirement of validity and effectiveness criteria in training critical thinking.
\end{abstract}

Key words: Science Learning Material with Local Wisdom, Critical Thinking.

\section{Introduction}

Science learning is an important lesson and must be mastered by students. Its implementation must be appropriate in terms of essence and purpose of knowledge as discipline [1][3]. The essential and purpose of the learning [3][4] are to develop: (1) knowledge and scientific conceptual understanding of daily life, (2) curiosity, positive attitude, and awareness to correlate to surrounding environment, (3) processing ability in investigating surrounding nature, solving problems, and making decision, and (4) interest to recognize and learn surrounding events or matters. Once learners realize them, then they are said to have developed critical thinking.

The facts of science learning is - poorly training students to think critically [4]. Poor critical thinking occurs sinceduring learning science, it is still far from expectation [4][5][6]. Teachers still emphasize to achieve Basic Competence determined in teaching instruments so they poorly teach them thinking critically.

Critical thinking [7][8][9] is grouped into five aspects: (1) elementary clarification, (2) the basis for the decision, (3) inference, (4) advanced clarification, and (5) supposition and integration.

From the problem, training of critical thinking can be done by developing learning material. [2][10][12] argued an integration between science learning and local wisdom can be 
done. Science learning based local wisdom has benefits to introduce learners about scientific concepts and facts as well as an effort to train critical thinking to observe and utilizing a surrounding natural phenomenon occurrence.

The statement is also supported by previous findings such as [1][7][12][13] about science learning material development by integrating local wisdom which was reliable to implement and was capable to train scientific concept mastery as well as critical thinking. Therefore, there is an investigation needed titled "The Development of Science Learning Material with Local Wisdom to Train Students' Critical Thinking”.

\section{Method}

This 4-D development model research (Define, Design, Develop, and Disseminate) [14]. Its procedure consists of investigating potency and problems based observation conducted at SMP Negeri 2 Selomerto, Wonosobo Regency, as preliminary study to define the data. Designing product stage designs learning material to be in line with purpose. Validating product stage involves expert validators and science practitioners which lately is followed up by revision Develop. The final stage is distribution of the learning material for eighth graders of the school, selected by purposive sampling Disseminate. The instruments were learning material validity sheet and multiple choice [8][9][10], "The Cornel Critical Thinking X".The research design is one group pretest-posttest with $\mathrm{N}$-Gain test and paired sample t-test.

\section{Result and Discussion}

\subsection{Product Development Validity}

As supportive data to gain valid and reliable results to explain the students' critical thinking from whole learning activities, then validity is not only conducted on learning material but also syllabus, lesson plan, and evaluative instruments of vibration, wave, and sound themes.

The product validity components are: content reliability, presentation, and language [11][12]. The data of validity is shown below.

Table 1. Expert Validity Result

\begin{tabular}{llll}
\hline No. & Product & Score & Category \\
\hline 1. & Syllabus & 80 & Valid \\
2. & Lesson plan & 85.33 & Very Valid \\
3. & Learning Material & 70.32 & Valid \\
4. & Learning Material(Medium) & 89.09 & Very Valid \\
5. & Critical Thinking Test & 80 & Valid \\
\hline Average Score and Category & 80.94 & Valid \\
\hline
\end{tabular}


Table2. Science Practitioner Validity Result

\begin{tabular}{llll}
\hline No. & Product & Score & Category \\
\hline 1. & Syllabus & 95.46 & Very Valid \\
2. & Lesson plan & 96.67 & Very Valid \\
3. & Learning Material & 81.94 & Valid \\
4. & Learning Material(Medium) & 96.64 & Very Valid \\
\hline \multicolumn{2}{l}{ Average Score and Category } & 92.68 & Very Valid \\
\hline
\end{tabular}

Based on the tables, expert and practitioner's judgments to the product were 80.94 and 92.68, categorized (valid and very valid). It meant the validators appreciated the product. The influential factors of the product validity were caused by design adjustments: (1) indicators determined on validity instrument, (2) relevancy of content and theory to objective formulation principles among components arranged systematically, and (3) an integration of positive value local wisdom which attracted the validators.

After internal validation, it was continued by testing external validity. It focuses on critical thinking test. Results gained by using Anates Version 4.0 analyzing program proved it valid since $r_{\text {calculated }}>r_{\text {table }}$, categorized significant. It was influenced by test design which was in line with characteristics of students' intellectual [15][17][18].

\subsection{Effective of the Product to Train Critical Thinking}

The product effectiveness focused on learning material could be measured how the average improvement score of critical thinking before (pretest) and after intervention (posttest) by using the learning material under themes: vibration, wave, and sound with local wisdom through $\mathrm{N}$-gain test shown in Table 3.

Table3. Critical Thinking Result

\begin{tabular}{lll}
\hline & Before & After \\
\hline Average of & 30.22 & 81.22 \\
$N$-gain & 0.73 & \\
Category & High & \\
\hline
\end{tabular}

Then, hypothesis test by using paired sample t-test showed sig $0.000<\alpha=0.05$, indicating significant difference of critical thinking scores between before and after intervention. It means the learning material was effective to train critical thinking of the students.

Influential factors to high critical thinking scores of the students by using the learning material was generally caused by demand for the students to be active in gaining experience through scientific phenomenon observation. According [7][18][20][21][22] could train critical thinking and influenced students' characteristics and learning achievements.

Furthermore, specifically, the learning material with its aid, "Bundengan" - a traditional musical instrument of Wonosobo, which was used during learning provided students: (1) to actively learn, (2) to cooperatively learn, and (3) to contextually learn. According $[8][9][10][18][22]$, the activities could train critical thinking.

Active learning allowed students to actively participate by using "Bundengan" of the learning material to manage knowledge in answering scientific issues dealing with vibration, 
wave, and sound materials. The management skill of such knowledge influenced critical thinking from elementary clarification aspect [2][6][18].

Collaborative learning allowed the students to collaborate with group peers to select topic of the problems, plan effective solution, and take supportive data to solve the problems aided by "Bundengan". All activities according [8][9][10], influence critical thinking from: (1) elementary clarification,(2) the basis for the decision, (3) inference, (4) advanced clarification,and (5) supposition and integrationaspects.

Contextual learning, by using "Bundengan", allowed students to: (1) construct new knowledge based on background knowledge through interactional process among the students (constructivism) to explain simple natured matters; (2) trigger new knowledge to make students more critical in observing each step of "Bundengan" application on the material (questioning). [10][13][18][22], the activities could influence critical thinking on: elementary clarification, (2) the basis for decision, and (3) inference aspects.

\section{Conclusion}

The development of "Science Learning Material with Local Wisdom Content" influenced validity and effectiveness criteria to train student's critical thinking. 


\section{Reference}

[1] Ulandari, F.S, Wahyuni, S and Bachtiar, R.W. :Pengembangan Modul Berbasis Saintifik untuk Melatih Kemampuan Berpikir Kritis Pada Materi Gerak Harmonis di SMA Balung. Jurnal Pembelajaran Fisika. Vol. 7, pp. 15-21 (2018).

[2] Dewi, N.P.S.R, Wibawa, I.M.C and Devi, N.L.P.L. :Kemampuan Berpikir Kritis dan Keterampilan Proses dalam Pembelajaran Siklus Belajar $7 E$ Berbasis Kearifan Lokal. Jurnal Pendidikan Indonesia. Vol. 6, pp. 125-133 (2017).

[3] Afandi \& Sajidan. Stimulasi Keterampilan Berpikir Tingkat Tinggi. 2018.

[4] Wahyuni, S. :Pengembangan Bahan Ajar IPA untuk Meningkatkan Kemampuan Berpikir Kritis Siswa SMP. Jurnal Materi dan Pembelajaran Fisika. Vol. 5, pp. 47-52 (2015).

[5] OECD. PISA 2015 Result: Executive Summary. 2016.

[6] As'ari, A.R. :Ideas For Developing Critical Thinking At Primary School Level. Proceeding International Seminar on Addressing Higher Order Thinking. Critical Thinking Issues in Primary Education, pp. 1-13 (2014).

[7] Satriawan, M and Rosmiati. :Pengembangan Bahan Ajar Fisika Bermuatan Kontekstual dengan Mengintegrasikan Kearifan Lokal untuk Meningkatkan Pemahaman Konsep Fisika pada Mahasiswa. Prosiding Seminar Pendidikan Sains Pascasarjana Universitas Negeri Surabaya,pp. 1212-1217 (2016).

[8] Eniss,R.H.CriticalThinking. 2000

[9] Ennis, R.H. The Nature of Critical Thinking: An Outline of Critical Thinking Dispositions and Abilities. 2011.

[10] Ardhiansyah, F. :Critical Thinking Skill of XI Grade Students SMA Muhammadiyah 1 Purwokerto With Bioentrepreneurship Based Learning. Proceedings International Conference on Indonesia Islam, Education and Science (ICIIES) 2017, pp. 685-689 (2017).

[11] Susastra, W. I. :Model Pembelajaran Fisika untuk Mengembangkan Kreativitas Berpikir dan Karakter Bangsa Berbasis Kearifan Lokal Bali. Jurnal Pendidikan Indonesia. Vol. 2, pp. $221-$ 235 (2018).

[12] Oktaviana, D, Hartini, S and Misbah. :Pengembangan Modul Fisika Berintegrasi Kearifan Lokal Membuat Minyak Lala untuk Melatih Karakter Sanggam. Jurnal Berkala Ilmiah Pendidikan Fisika. Vol. 5, pp. 272-285 (2017).

[13] Oktaviani, W, Gunawan and Sutrio. :Pengembangan Bahan Ajar Fisika Kontekstual untuk Meningkatkan Penguasaan Konsep Siswa. Jurnal Pendidikan Fisika dan Teknologi. Vol. 3, pp. 1-7 (2017).

[14] Thiagarajan, S, Semmel, S.D and Semmel, M.I. Instructional Development for Training Teacher of Expectional Children. 1974.

[15] Mabruroh, F and Suhandi, A. :Construction of Critical Thinking Skills Test Instrument Related The Concept on Sound Wave. IOP Conference Series: Journal of Physic: Conference Series, pp. 1-6 (2017).

[16] Lestari, I. Pengembangan Bahan Ajar Bermuatan Kompetensi. 2018.

[17] Mulyani, R, Saminan and Sulastri. :Peningkatan Kemampuan Berpikir Kritis Peserta Didik Melalui Implementasi Lembar Kerja Peserta Didik Berbasis Predict Observe Explain.Jurnal Pendidikan Sains Indonesia. Vol. 5, pp. 19-24 (2017).

[18] Changwong, K, Sukkamart, A and Sisan, B. :Critical thinking skill development: Analysis of a new learning management model for Thai high schools. Journal of International Studies. Vol. 11, pp. 37-48 (2018).

[19] Kanhadilok, P and Watts, M. :Western Science and Local Thai Wisdom: Using Museum Toys to Develop Bi-Gnosis. Canadian Journal of Science, Mathematics and Technology Education. Vol. 13 , pp. 33-48 (2013). 
[20] Nurgraha, D.A, Binadja, A and Supartono. :Pengembangan Bahan Ajar Reaksi Redoks Bervisi SETS, Berorientasi Kontruktivistik. Journal of Innovative Science Education. Vol. 2, pp. 28-34 (2013).

[21] Huynh, A. C and Grossmann, I. :A Pathway for Wisdom-Focused education. Jurnal of Moral Education, pp.1-21 (2018).

[22] Halim, L and Mokhtar, L.E. :Critical Thinking Process in Science Learning. Prosiding Seminar Nasional Pendidikan Sains V" Pengembangan Model dan Perangkat Pembelajaran untuk Meningkatkan Kemampuan Berpikir Tingkat Tinggi”, pp. 1-4 (2015). 